\title{
Utilization of Chicken By-Products to Form Collagen Films
}

\author{
Kumudini A. Munasinghe, ${ }^{1}$ Jurgen G. Schwarz, ${ }^{2}$ and Matthew Whittiker ${ }^{2}$ \\ ${ }^{1}$ Department of Biological Sciences, Salisbury University, Salisbury, MD 21801, USA \\ ${ }^{2}$ Food Science and Technology Ph.D. Program, Department of Agriculture, Food and Resource Sciences, \\ University of Maryland Eastern Shore, Princess Anne, MD 21853, USA \\ Correspondence should be addressed to Kumudini A. Munasinghe; kamunasinghe@salisbury.edu
}

Received 15 June 2014; Accepted 15 December 2014

Academic Editor: Ma Murcia

Copyright (C) 2015 Kumudini A. Munasinghe et al. This is an open access article distributed under the Creative Commons Attribution License, which permits unrestricted use, distribution, and reproduction in any medium, provided the original work is properly cited.

\begin{abstract}
Chicken collagen casings could be an alternate source of collagen casings that are manufactured for sausages. The overall objective of this project was to extract chicken collagen from by-products of the broiler processing industries and to explore the possibility of making films. Chicken skin was washed, ground, and pretreated to remove the noncollagenous compounds. Collagen was extracted using acetic acid and pepsin. Solubilized collagen was salted-out and centrifuged at 20,000 $\times \mathrm{g}$ at $4^{\circ} \mathrm{C}$ for one hour. The precipitates were dissolved in $0.5 \mathrm{M}$ acetic acid and dialyzed against $0.1 \mathrm{M}$ acetic acid and distilled water before freeze-drying. Molecular weight, collagen solubility at different $\mathrm{pH}$ values, and $\mathrm{NaCl}$ concentrations were determined. TA-XT2 texture analyzer was used to characterize mechanical properties of collagen films. The highest collagen solubility was obtained at $\mathrm{pH} 2$ and $2 \% \mathrm{NaCl}$. Handhomogenized, nonfiltered, and conditioned samples had the highest hardness $(3,262 \mathrm{~g})$ and the least brittleness $(30.5 \mathrm{~mm})$. These results demonstrate that chicken collagen extracted from chicken by-products has the ability to form films and could be considered for making casings or be used in various other industries.
\end{abstract}

\section{Introduction}

Natural casings may have high bacterial loads, need to be preserved, and are more labor-intensive to handle than reconstituted casings [1]. Edible collagen films can be formed into collagen casings. Collagen casings play an important role in manufacturing process of sausages. Collagen casings can inhibit bacterial attachment as well as enhance the hygienic properties of sausages [2].

The chicken processing industry is an important income generator in Delmarva Peninsula. Annual broiler production is approximately 8.9 million pounds in 2009 [3]. Waste generated by the chicken processing plants can be minimized by utilizing chicken by-products. Collagen extraction from chicken by-products minimizes the waste production of chicken industry.

Lucca and Ferraz da Silva Torres [4] studied the conditions of hot dog processing in Brazil and found that the hygienic conditions for food preparations were extremely poor. Consumers were at high risk due to unsuitable hygienic practices during food preparation and the lack of basic knowledge regarding safe food handling that causes public health problems. Although all hot dogs are fully cooked, they should always be reheated before eating. The effect of reheating on the viability of a five-strain mixture of Listeria monocytogenes in vacuum-sealed packages of frankfurters following refrigerated or frozen storage was studied by Porto et al. [5]. It was suggested that frankfurters which may become contaminated with low levels of L. monocytogenes prior to packaging and after unpackaging should be adequately reheated prior to consumption. Thus, for added precaution, persons at risk may choose to avoid eating sausages type foods unless they are reheated to $140^{\circ} \mathrm{C}$ [6]. So to speak, incident of L. monocytogenes can be minimized if sausages have edible casings.

Collagen casings are important in manufacturing sausages to maintain its specific shape. The earliest forms of natural collagen casings are casings from bovine and porcine intestines. Casings made from extruded, reconstituted collagen fibers are popular compared to natural casings 
because fabricated collagen casings offer the advantages of uniformity, strength, flexibility, and greater consistency in processing environments compared to natural casings.

Chicken collagen was mixed with acetic acid, glutaraldehyde, carboxymethyl cellulose (CMC), sorbitol, sodium chloride $(\mathrm{NaCl})$, hydrochloric acid $(\mathrm{HCl})$, and glycerol to form collagen films. Acetic acid and carboxymethyl cellulose were used to improve the strength. Plasticizing agent glycerol/sorbitol and cross-linking agent glutaraldehyde were used to improve the pliability of the film and also to overcome film brittleness caused by extensive intermolecular forces [1]. It was found that if the concentration of glutaraldehyde exceeds $0.2 \%$, the maximal viscosity of collagen gel solutions reaches a plateau [7]. Drying, conditioning, and neutralizing provide additional cross-linking of the collagen casings made up of bovine collagen, Gennadios [8]. Fernandes et al. [9] used acrylic containers to dry collagen films made up of porcine in a vacuum atmosphere.

The ability to form chicken collagen films from the extracted collagen samples from chicken by-products would indicate the possibility of making collagen casings which are important in the production of a variety of value-added or processed meat products. Collagen extracted from one-step acid and pepsin procedure was selected to make collagen films because this method gave higher yield and had less processing time [10].

\section{Material and Methods}

2.1. Raw Material Preparation and Pretreatment. Material preparation was adopted from Kittiphattanabawon et al. [11]. Broiler chicken (Perdue Farms, Salisbury, MD) skin was cleaned with tap water and skin samples were cut into small pieces $\left(0.5 \times 0.5 \mathrm{~cm}^{2}\right)$ before storing at $-20^{\circ} \mathrm{C}$. Removal of noncollagenous proteins, fat, and inorganic matter was conducted at $4^{\circ} \mathrm{C}$ with continuous stirring. Noncollagenous protein was removed by constantly mixing the samples of skins with $0.1 \mathrm{~N} \mathrm{NaOH}$ at a sample/alkali solution ratio of 1:6(w/v). The mixture was stirred for 6 hours. Every 2 hours, the alkali solution was changed. Then the sample was washed with distilled water, until the water was clear and colorless. The deproteinized skin samples were defatted with $10 \%$ butyl alcohol with a solid/solvent ratio of $1: 6(\mathrm{w} / \mathrm{v})$. The mixture was stirred for 24 hours. Every 6 hours, the solvent was changed. Then the defatted samples were washed with distilled water three times. Inorganic compounds were removed by soaking the defatted sample in a $0.1 \mathrm{~N} \mathrm{HCl}$ solution with a solid/solvent ratio of $1: 6(\mathrm{w} / \mathrm{v})$. The mixture was stirred for 24 hours. Then, the sample was filtered through double layer cheesecloth and washed three times with distilled water [12].

2.2. Collagen Extraction and Precipitation. $0.5 \mathrm{M}$ acetic acid containing pepsin $(20 \mathrm{kU} / \mathrm{g}$, Sigma-Aldrich Corp., St. Louis, MO) was used to soak defatted samples for 48 hours at $4^{\circ} \mathrm{C}$. The solid/solvent ratio was $1: 6(\mathrm{w} / \mathrm{v})$. The mixture was filtered with a double layer of cheesecloth and the filtrates were collected for precipitation [13]. The collagen extractions were precipitated according to the method described by
Kittiphattanabawon et al. [11]. $\mathrm{NaCl}$ was used for the precipitation until final concentration reaches $2.6 \mathrm{M}$ in the presence of $0.05 \mathrm{M}$ tris(hydroxymethyl)aminomethane ( $\mathrm{pH} 7.0)$. The precipitates were collected by centrifuging at $20,000 \times \mathrm{g}$ for $60 \mathrm{~min}$ at $4^{\circ} \mathrm{C}$ and the pellets were dissolved in $0.5 \mathrm{M}$ acetic acid. Then the pellets were dialyzed against $0.1 \mathrm{M}$ acetic acid and distilled water.

2.3. Collagen Solubility. The method described by Montero et al. [14] was used to determine solubility of collagen with slight modifications. To obtain a stock solution of $8 \mathrm{mg} / \mathrm{mL}$, collagen was dissolved in $0.5 \mathrm{M}$ acetic acid and the mixture was stirred at $4^{\circ} \mathrm{C}$ until the collagen completely solubilized.

2.3.1. Effect of $p H$ on Collagen Solubility. Six aliquots of the collagen stock solution $(10 \mathrm{~mL})$ were placed in $50 \mathrm{~mL}$ centrifuge tubes (Fisher Scientific, Pittsburgh, PA) and the $\mathrm{pH}$ adjusted to 2, 4, 6, 8, 10, and 12 using $6 \mathrm{~N} \mathrm{NaOH}$ or $6 \mathrm{~N} \mathrm{HCl}$. Samples were centrifuged at $20,000 \times \mathrm{g}$ and $4^{\circ} \mathrm{C}$ for $30 \mathrm{~min}$. Supernatants were subjected to protein measurement. The Bradford assay was used to measure the absorbance at $595 \mathrm{~nm}$ wavelength [15]. Bovine serum albumin was used as the standard and calculations were directly proportional to the standard curve.

2.3.2. Effect of $\mathrm{NaCl}$ on Collagen Solubility. Collagen solution $(5 \mathrm{~mL})$ was mixed with $5 \mathrm{~mL}$ of $\mathrm{NaCl}$ at various concentrations $(0 \%, 2 \%, 4 \%, 6 \%, 8 \%, 10 \%$, and $12 \% \mathrm{w} / \mathrm{v})$. The mixtures were stirred for $30 \mathrm{~min}$ at $4^{\circ} \mathrm{C}$ and centrifuged for $30 \mathrm{~min}$ at $20,000 \times \mathrm{g}$ at $4^{\circ} \mathrm{C}$. Supernatants were collected separately and protein content was measured using the Bradford assay following the same procedure described in Section 2.3.1.

2.4. Collagen Film Formation. Film-forming solutions were prepared by mixing $8 \mathrm{~g}$ of collagen samples with glycerol, sorbitol, carboxymethyl cellulose (CMC), and glutaraldehyde. The mixture was poured on polystyrene weighing dish to cast films. Then they were air-dried at room temperature for 48 hours. The dry films which had a water activity of 0.8 were carefully recovered from the weighing dishes to conduct conditioning procedures. Conditioning was conducted with $0.1 \mathrm{M} \mathrm{HCl}$ and $0.1 \mathrm{NaOH}$ several times with slow agitation for $15 \mathrm{~min}$. During conditioning collagen films were washed with distilled water between each treatment with $0.1 \mathrm{M} \mathrm{HCl}$ and 0.1 $\mathrm{NaOH}$.

2.5. Texture Analysis. TA-XT2 texture analyzer was used to analyze the texture of collagen films using the flat blade probe (Table 3). The hardness and brittleness of the films which were formed in different ways were measured. The hardness is the peak force ( $\mathrm{g}$ ) of the compression required for the sample's breakage and the brittleness is the distance from zero force to peak force. Higher peaks indicated higher hardness and samples which have longer distance indicated less brittleness of the film.

\section{Results and Discussion}

3.1. Collage Extraction Using One-Step Acetic Acid and Pepsin Extraction Procedure. Jongjareonrak et al. [16] reported that 
TABLE 1: Collagen solubility in different $\mathrm{pH}$ values.

\begin{tabular}{lc}
\hline Sample ID & Protein content $(\mathrm{mg} / \mathrm{mL})^{\mathrm{a}}$ \\
\hline pH 2 & $0.16 \pm 0.51$ \\
pH 4 & $0.05 \pm 0.08$ \\
pH 6 & $0.05 \pm 0.07$ \\
pH 8 & $0.04 \pm 0.04$ \\
pH 10 & $0.08 \pm 0.07$ \\
\hline
\end{tabular}

${ }^{\mathrm{a}}$ Mean of two observations.

the pepsin digested procedures gave a complete digestion for chicken skin and also there was no intact skin left with pepsin after 48 hours digestion. Nalinanon et al. [13] suggested that use of acetic acid makes skin more porous, therefore, enhancing pepsin digestion. Further, they suggested that more molecular cross-links between collagen and other components can be broken by the additional digestion with pepsin. After comparing yields of five different extraction procedures with $0.5 \mathrm{M}$ acetic acid, $0.5 \mathrm{M}$ citric acid, alkali extraction, one-step acetic acid and pepsin extraction and two-step acidic acid and pepsin extraction [10], one-step acetic acid and pepsin extraction was performed to extract collagen to form collagen films because of the high yield of collagen $(38.7 \%)$.

\subsection{Collagen Solubility}

3.2.1. Chicken Collagen Solubility at Different $p H$ Values. Pepsin extracted collagen was dissolved in $0.5 \mathrm{M}$ acetic acid to obtain a final concentration of $8 \mathrm{mg} / \mathrm{mL}$ and the $\mathrm{pH}$ of the solution was adjusted using $6 \mathrm{~N} \mathrm{NaOH}$ or $6 \mathrm{~N} \mathrm{HCl}$. The Bradford assay was used to measure the absorbance at a wavelength of $595 \mathrm{~nm}$. Bovine serum albumin was used as the standard and calculations were directly proportional to the standard curve. The highest solubility of $0.16 \mathrm{mg} / \mathrm{mL}$ occurred at $\mathrm{pH} 2$ and the lowest solubility of $0.05 \mathrm{mg} / \mathrm{mL}$ occurred at pH 8 (Table 1). Collagen solubility in $\mathrm{pH} 10$ was $0.08 \mathrm{mg} / \mathrm{mL}$. This solubility behavior is typical for proteins, which tend to carry a positive charge at low $\mathrm{pH}$ and a negative charge at high $\mathrm{pH}$. Molecules with the same charge repel each other and increase solubility. At an intermediate $\mathrm{pH}$, proteins reach their isoelectric point.

At the isoelectric point net charge of a protein molecule is zero and the repulsion forces are minimized. This leads to the aggregation of protein molecules and decreased solubility [14].

Jongjareonrak et al. [16] found that acid and pepsin extracted collagens from bigeye snapper skin exhibited the lowest solubility between $\mathrm{pH}$ values of 6 and 7. Kittiphattanabawon et al. [11] observed the lowest solubility of acid extracted collagen from bigeye snapper skin was at $\mathrm{pH}$ 7. The result of this study shows that the lowest chicken collagen solubility was at $\mathrm{pH} 8$. However, the $\mathrm{pH}$ values tested in this study were $\mathrm{pH} 6$ and $\mathrm{pH} 8$ and did not include $\mathrm{pH} 7$ so that a direct comparison for the solubility at this $\mathrm{pH}$ is not possible.
TABLE 2: Collagen solubility in different $\mathrm{NaCl}$ concentrations.

\begin{tabular}{lc}
\hline Sample ID & Protein content $(\mathrm{mg} / \mathrm{mL})^{\mathrm{a}}$ \\
\hline $\mathrm{NaCl} \mathrm{2 \%}$ & $0.11 \pm 0.1$ \\
$\mathrm{NaCl} 4 \%$ & $0.02 \pm 0.02$ \\
$\mathrm{NaCl} \mathrm{6 \%}$ & $0.01 \pm 0.04$ \\
$\mathrm{NaCl} 8 \%$ & Not detected \\
$\mathrm{NaCl} \mathrm{10 \%}$ & Not detected \\
$\mathrm{NaCl} \mathrm{12 \%}$ & Not detected \\
\hline
\end{tabular}

${ }^{a}$ Mean of two observations.

TABLE 3: Collagen film parameters for texture analyzer.

\begin{tabular}{lcc}
\hline Filter ID number & Maximum force $(\mathrm{g})$ & Distance $(\mathrm{mm})$ \\
\hline Film 1 & 3262 & 30.5 \\
Film 2 & 16037 & 5.8 \\
Film 3 & 500 & 26.3 \\
Film 4 & 4102 & 26.7 \\
Film 5 & 740 & 14.8 \\
\hline
\end{tabular}

mixed with $5 \mathrm{~mL}$ of $\mathrm{NaCl}$ solution of different concentrations $(2,4,6,8,10$, and $12 \%)$. The highest solubility $(0.11 \mathrm{mg} / \mathrm{mL})$ was obtained at $2 \% \mathrm{NaCl}$ (Table 2). Solubility at 4 and $6 \%$ $\mathrm{NaCl}$ was 0.02 and $0.01 \mathrm{mg} / \mathrm{mL}$, respectively. No solubility was detected for the protein at $\mathrm{NaCl}$ concentrations of 8 , 9 , and $10 \%$. The Bradford test may not be sensitive enough to measure low values of proteins because the sensitivity of Bradford assay is $0.01 \mathrm{mg} / \mathrm{g}$ of protein [17]. This result is in agreement with the report by Nalinanon et al. [13] who found that the solubility of collagens decreased gradually with increasing $\mathrm{NaCl}$ concentration. Vojdani [18] explained that a higher concentration of $\mathrm{NaCl}$ might result in decreased protein solubility via a salting-out effect.

Collagen solubility in different $\mathrm{NaCl}$ concentration (Table 2) decreased by increasing hydrophobic interaction and aggregation, and also $\mathrm{NaCl}$ competes with the protein for water.

In addition, ions from $\mathrm{NaCl}$ could also neutralize charges on proteins reducing electrostatic interaction and repulsion; thereby it was favoring the hydrophobic aggregation as well.

3.3. Film Formation with Collagen. The ability of forming films from the extracted collagen samples would indicate the possibility of making collagen casings which are important in the production of a variety of value-added or processed meat products. Collagen extracted from one-step acid and one-step pepsin was selected to make collagen films because this method gave higher yields (38.7\%) and the samples were easier to handle than those from the two-step acid and onestep pepsin method during collagen extraction procedures [10].

Glycerol and sorbitol were added to the film-forming solutions as plasticizers. This reduced the brittleness caused by extensive intermolecular forces. Gennadios et al. [1] showed that collagen films have limited resistance to water vapor transmission and require a significant amount of plasticizers (sorbitol and glycerin) to impart flexibility. 


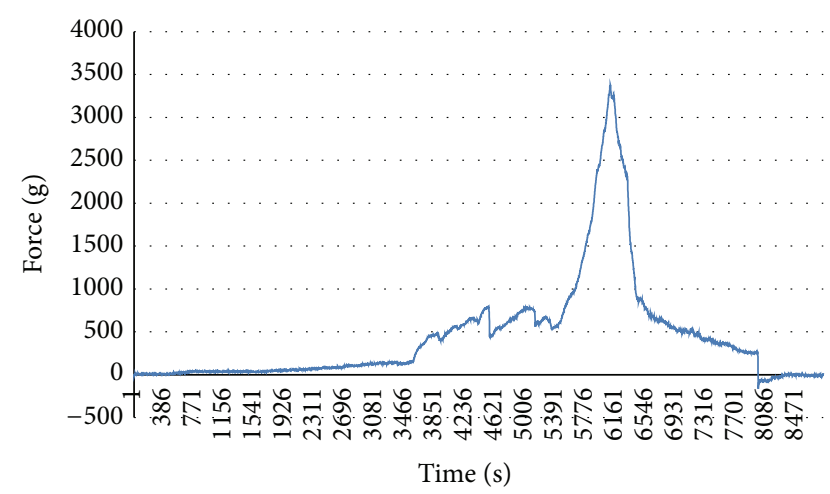

FIGURE 1: Film 1: hand-homoginized, nonfiltered, and conditioned film (8g).

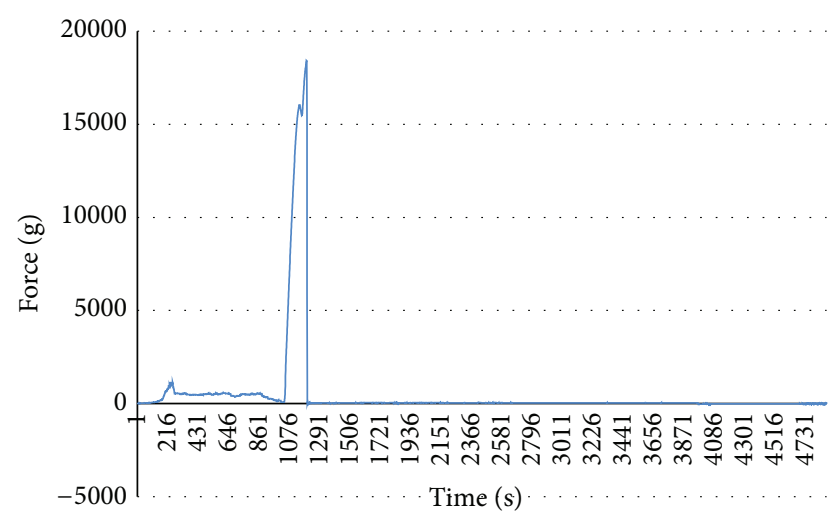

FIGURE 2: Film 2: hand-homogenized, nonfiltered, and conditioned thin film $(8 \mathrm{~g})$.

3.4. Comparison of Collagen Films. Figures 1, 2, 3, 4, and 5 show the texture analysis results for the films which had different processing procedures. Film 1 was hand-homogenized, nonfiltered, and conditioned and used $8 \mathrm{~g}$ of slurry and Film 2 was hand-homogenized, nonfiltered, and conditioned and it was a thinner film using less than $8 \mathrm{~g}$ of slurry. Film 3 was formed from a hand-homogenized, filtered, and nonconditioned sample using $8 \mathrm{~g}$ of slurry to make a film. Film 4 was formed from hand-homogenized filtered slurry $(8 \mathrm{~g})$ and was conditioned. Film 5 was from a machine homogenized sample and used $8 \mathrm{~g}$ of slurry. Machine homogenized samples did not form a film that could go through in the conditioning steps. Film 2 had the highest peak of $16037 \mathrm{~g}(160 \mathrm{~N})$ and the shortest distance of $5.8 \mathrm{~mm}$. It was the hardest film and also the most brittle film. Films 1 and 4 were much harder and less brittle than Films 3 and 5 which were the softest and least brittle.

The film obtained from the collagen slurry mixed with the Ultra-Turrax T25 high speed homogenizer maintained a soft texture and was hard to remove from the weighing dish. However, films obtained from hand-mixed samples were very easy to remove from the weighing dishes when they were properly dried.

Proper appearance could be obtained when the handmixed samples were filtered through a double layer of

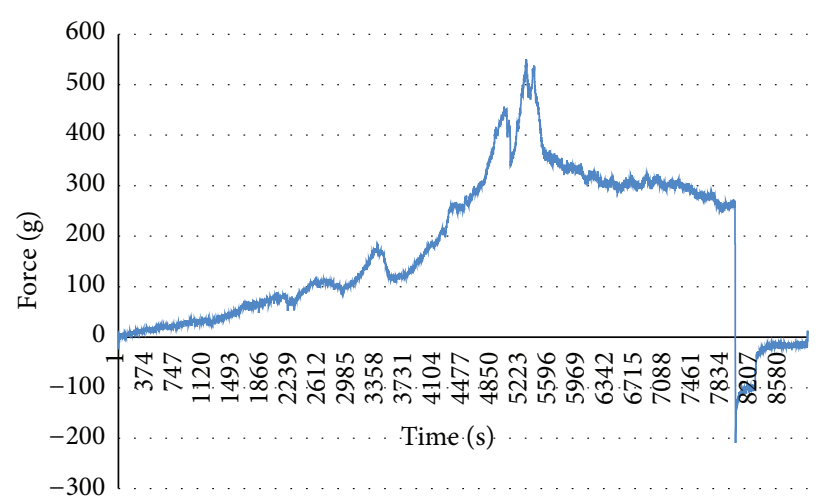

FIGURE 3: Film 3: hand-homoginized, filtered, and nonconditioned film (8g).

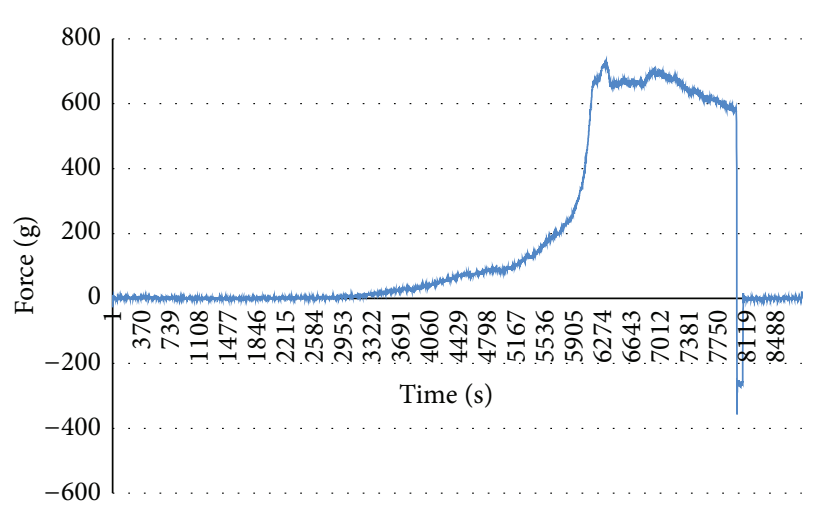

FIGURE 4: Film 4: hand-homogenized, filtered, and conditioned film (8g).

cheesecloth. However, those films were more brittle than nonfiltered collagen films.

Yellow coloration of the collagen film could be reduced by dipping collagen film in a $\mathrm{HCl}$ bath during the conditioning steps. Dipping collagen film in a $\mathrm{NaCl}$ bath can increase cross-links according to Gennadios et al. [1]. Also drying, conditioning, and neutralizing provided additional crosslinking of the collagen film as reported by Hood et al. [19]. After being washed with distilled water, films were dried under an air flow at room temperature until the water activity reached a level of 0.8 . Then the collagen films were stored at room temperature.

\section{Conclusion}

Chicken skin extracted with one-step acid and one-step pepsin was selected as the source for the experimentation to manufacture collagen film because of its high yield $(38.7 \%)$ after conducting pretreatment procedures to remove fat and minerals.

The extracted colorless and odorless chicken collagen was used to find the solubility with different acid concentrations and salt concentrations. Collagen solubility was affected by $\mathrm{pH}$ level and $\mathrm{NaCl}$ concentration. The highest solubility 


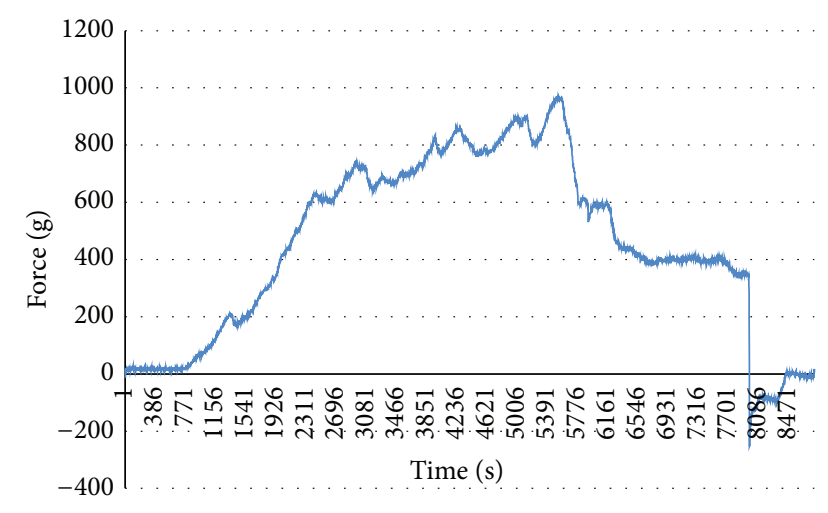

Figure 5: Film 5: machine homogenized film (8 g).

$(0.16 \mathrm{mg} / \mathrm{g})$ of collagen was obtained at $\mathrm{pH} 2$ and lowest solubility was obtained at $\mathrm{pH} 8(0.04)$. Highest solubility $(0.11 \mathrm{mg} / \mathrm{mL})$ of collagen with $\mathrm{NaCl}$ was at $2 \%$ and solubility decreased with increasing $\mathrm{NaCl}$ concentration. Soluble protein was not detected at $8 \%$ to $12 \% \mathrm{NaCl}$ concentration.

Collagen was mixed with acetic acid, glutaraldehyde, $\mathrm{CMC}$, sorbitol, and glycerol. High levels of $\mathrm{NaCl}$ shrink the collagen fibers in order to form a stronger film during the conditioning step. In addition, $\mathrm{HCl}$ improved the color. Texture analysis was conducted using five different methods of making collagen films to test their properties for hardness and brittleness. Hand-homogenized, nonfiltered/filtered, and conditioned ( $8 \mathrm{~g}$ ) film gave comparatively higher values for the hardness $(3262 \mathrm{~g} / 4102 \mathrm{~g})$ and less brittleness $(30.46 \mathrm{~mm} / 26.7 \mathrm{~mm})$. The results of this study indicate that opportunities exist for further development of collagen film by making casings from chicken collagen as an alternate source of collagen. Collagen extracted from the processing of different by-products could be used as an alternate source of collagen for other industries as well.

\section{Conflict of Interests}

The authors declare that there is no conflict of interests regarding the publication of this paper.

\section{Acknowledgments}

This work was supported by Evans-Allen project. The authors would like to thank Dr. Harter-Dennis at University of Maryland Eastern Shore for helping with statistical analysis. Special thanks are due to Banuja Munasinghe for assisting them with lab work. The authors also extend their thanks to Dr. Barbara Pollock and Dr. Dyane Cherrie for reviewing this paper.

\section{References}

[1] A. Gennadios, M. A. Hanna, and L. B. Kurth, "Application of edible coatings on meats, poultry and seafoods: a review," LWT_Food Science and Technology, vol. 30, no. 4, pp. 337-350, 1997.
[2] M. W. Schilling, S. P. Daigle, C. Z. Alvarado, N. G. Marriott, and H. Wang, "Effects of collagen addition on the functionality of PSE-like and normal broiler breast meat in a chunked and formed deli roll," Journal of Muscle Foods, vol. 16, no. 1, pp. 4653, 2005.

[3] “USDA economic research service”, 2009, http://awfw.org/wpcontent/uploads/pdf/USDALivestockReportAug2009.pdf.

[4] A. Lucca and E. A. Ferraz da Silva Torres, "Street-food: the hygiene conditions of hot-dogs sold in São Paulo, Brazil," Food Control, vol. 17, no. 4, pp. 312-316, 2006.

[5] A. C. S. Porto, J. E. Call, and J. B. Luchansky, "Effect of reheating on viability of a five strain mixture of Listeria moncytogenes in vacuum sealed packages of frankfurters following refrigerated of frozen storage," Journal of Food Protection, vol. 67, no. 1, pp. 71-76, 2004.

[6] FDA, Food Code, 2003, http://www.fda.gov/food/default.htm.

[7] H.-O. Ho, C.-W. Lin, and M.-T. Sheu, "Diffusion characteristics of collagen film," Journal of Controlled Release, vol. 77, no. 1-2, pp. 97-105, 2001.

[8] A. Gennadios, "Collagen casings," in Protein-Based Films and Coatings, pp. 445-461, CRC Press, Boca Raton, Fla, USA, 2002.

[9] R. M. T. Fernandes, R. G. Couto Neto, C. W. A. Paschoal, J. H. Rohling, and C. W. B. Bezerra, "Collagen films from swim bladders: preparation method and properties," Colloids and Surfaces B: Biointerfaces, vol. 62, no. 1, pp. 17-21, 2008.

[10] K. A. Munasinghe, J. G. Schwarz, and A. K. Nyame, "Chicken collagen from low market value by-products as an alternate source," Journal of Food Processing, vol. 2014, Article ID 298295, 6 pages, 2014.

[11] P. Kittiphattanabawon, S. Benjakul, W. Visessanguan, T. Nagai, and M. Tanaka, "Characterisation of acid-soluble collagen from skin and bone of bigeye snapper (Priacanthus tayenus)," Food Chemistry, vol. 89, no. 3, pp. 363-372, 2005.

[12] T. Nagai, E. Yamashita, K. Taniguchi, N. Kanamori, and N. Suzuki, "Isolation and characterisation of collagen from the outer skin waste material of cuttlefish (Sepia lycidas)," Food Chemistry, vol. 72, no. 4, pp. 425-429, 2001.

[13] S. Nalinanon, S. Benjakul, W. Visessanguan, and H. Kishimura, "Use of pepsin for collagen extraction from the skin of bigeye snapper (Priacanthus tayenus)," Food Chemistry, vol. 104, no. 2, pp. 593-601, 2007.

[14] P. Montero, F. Jiménez-Colmenero, and J. Borderìas, "Effect of $\mathrm{pH}$ and the presence of $\mathrm{NaCl}$ on some hydration properties of collagenous material from trout (Salmo irideus Gibb) muscle and skin," Journal of the Science of Food and Agriculture, vol. 54, no. 1, pp. 137-146, 1991.

[15] M. M. Bradford, "A rapid and sensitive method for the quantitation of microgram quantities of protein utilizing the principle of protein dye binding," Analytical Biochemistry, vol. 72, no. 1-2, pp. 248-254, 1976.

[16] A. Jongjareonrak, S. Benjakul, W. Visessanguan, and M. Tanaka, "Isolation and characterization of collagen from bigeye snapper (Priacanthus macracanthus) skin," Journal of the Science of Food and Agriculture, vol. 85, no. 7, pp. 1203-1210, 2005.

[17] T. Zor and Z. Selinger, "Linearization of the Bradford protein assay increases its sensitivity: theoretical and experimental studies," Analytical Biochemistry, vol. 236, no. 2, pp. 302-308, 1996. 
[18] F. Vojdani, "Solubility," in Methods of Testing Protein Functionality, pp. 11-60, 1st edition, 1996.

[19] L. L. Hood, A. M. Pearson, T. R. Dotson, and A. J. Bailey, Collagen in Sausage Casings: Advances in Meat Research Collagen as Food, vol. 4, Nostrand Reinhold, New York, NY, USA, 1987. 

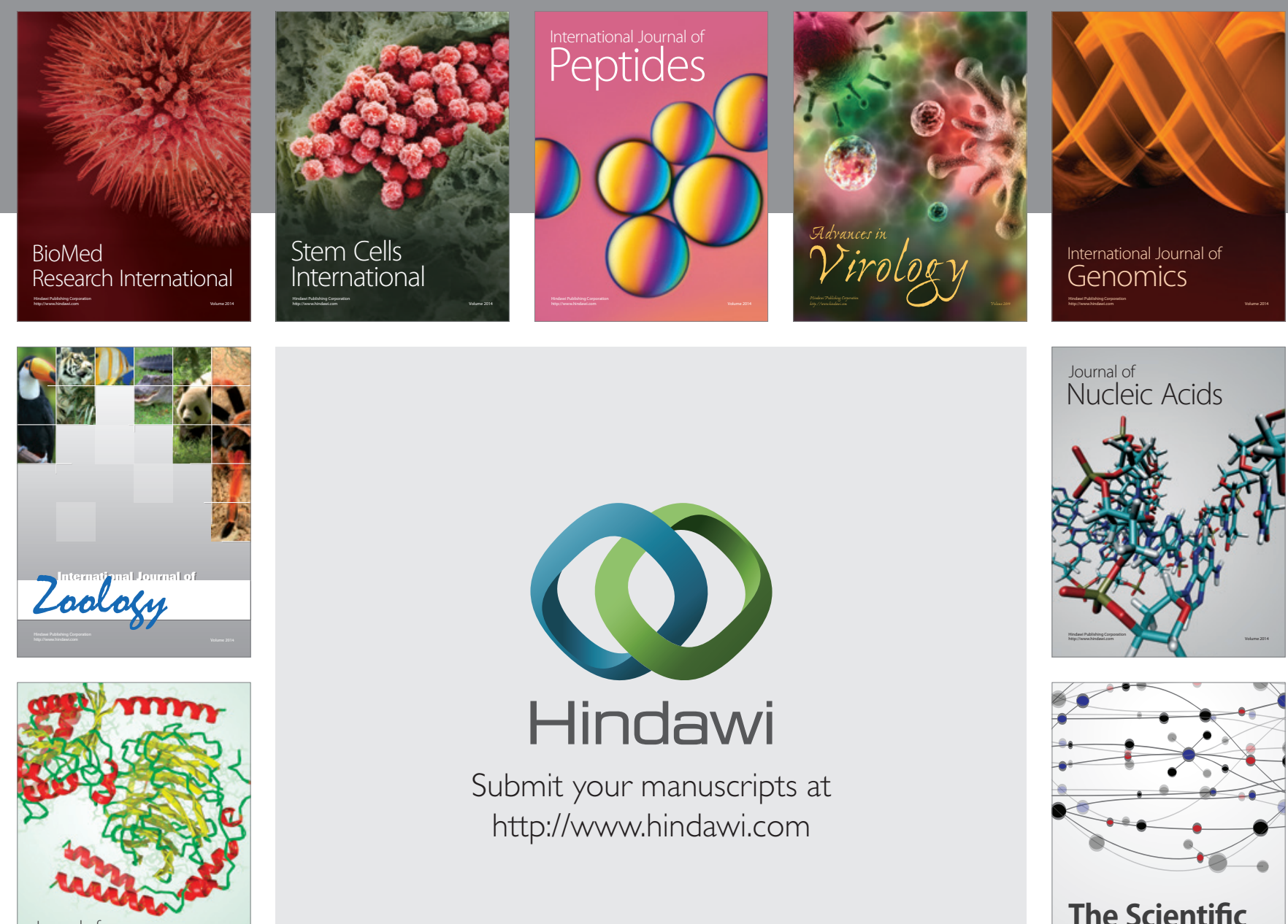

Submit your manuscripts at

http://www.hindawi.com

Journal of
Signal Transduction
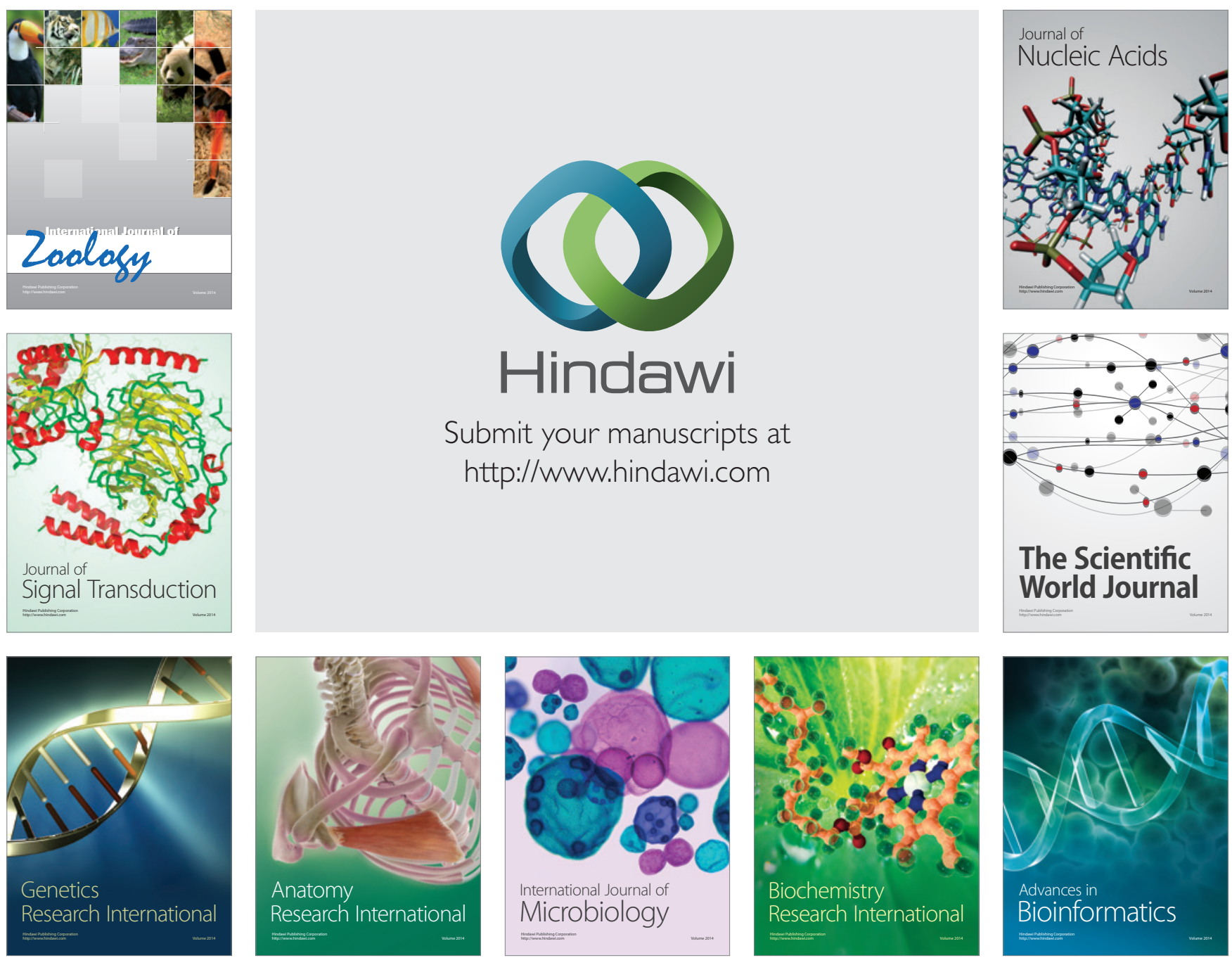

The Scientific World Journal
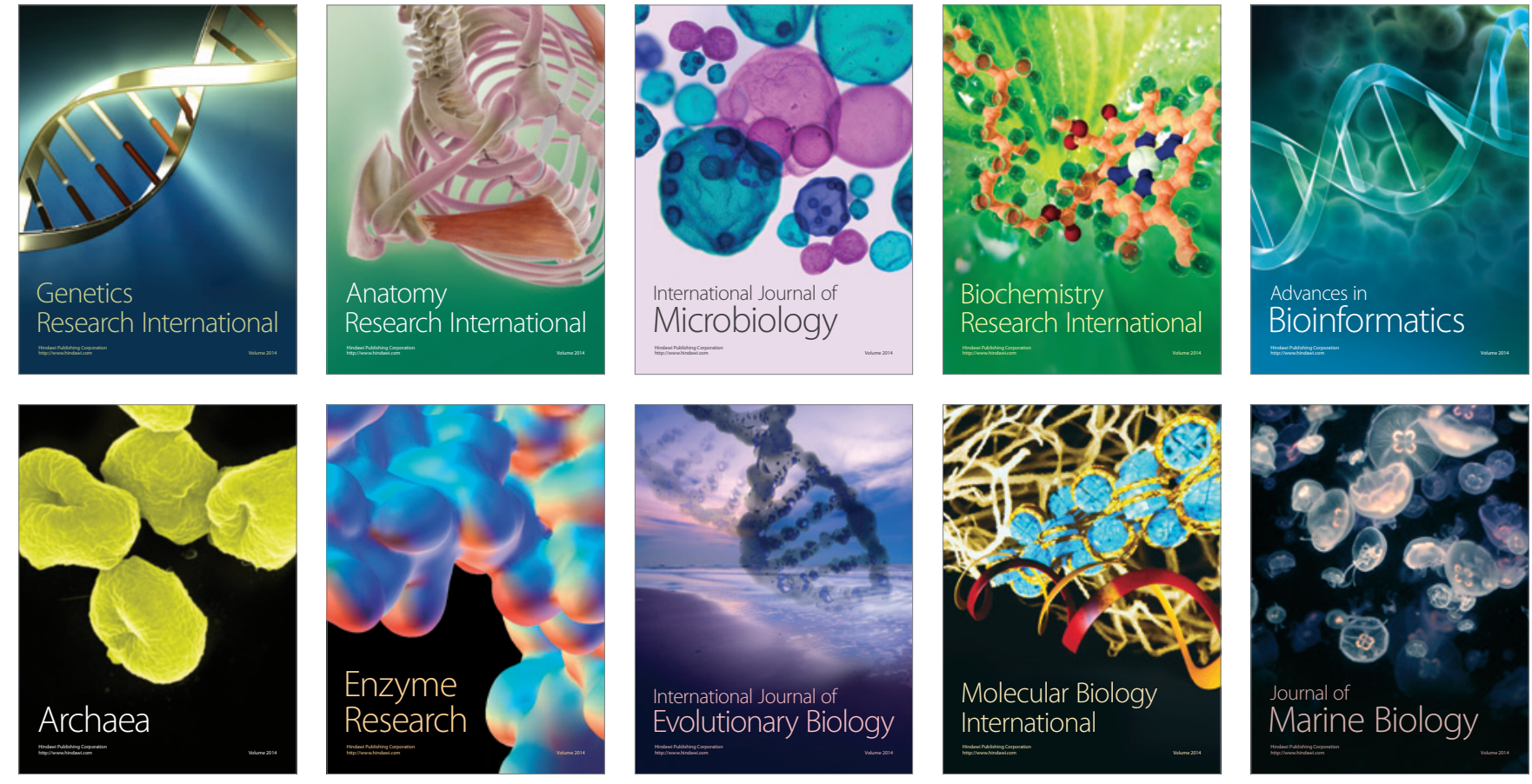